\title{
Factors Affecting the Development of Anxiety in Postmenopausal Women: A Cross-Sectional Study in Coastal Areas
}

\section{Faktor-Faktor yang Mempengaruhi Terjadinya Kecemasan pada Perempuan Pascamenopause: Suatu Studi Potong Lintang di Daerah Pesisir}

\author{
Juminten Saimin', Satrio Wicaksono², Junuda' ${ }^{2}$, Minarti \\ ${ }^{1}$ Department of Obstetrics and Gynecology \\ ${ }^{2}$ Departement of Psychiatry \\ Faculty of Medicine Halu Oleo University/ \\ Kendari
}

\begin{abstract}
Objective: To analyze factors associated with anxiety in postmenopausal women.

Methods: This study was descriptive analytic with cross-sectional approach conducted in 228 postmenopausal women that aged 50-64 years old in coastal areas of Kendari City. Samples were taken by simple random sampling. The technique of collecting data used questionnaires and the Taylor Manifest Anxiety Scale (T-MAS). Data were analyzed using Chi-square test with a significance value $\mathrm{p} \leq 0.05$.

Results: The results showed that 188 respondents (82.4\%) had anxiety. Its most experienced anxiety was aged 50-54 years old (37.7\%), low education (96.0\%), as housewife (62.7\%), low income $(91.2 \%)$ and lived with a partner $(54.4 \%)$. There was correlation between anxiety with age $(\mathrm{p}=0.016)$, education level $(\mathrm{p}=0.009)$, income $(p=0.011)$, and residence status $(p=0.029)$. There was no correlation between anxiety with occupation $(p=0.351)$.

Conclusion: There was a correlation between anxiety in postmenopausal women in coastal areas with age, education level, income, and residence status.

[Indones J Obstet Gynecol 2018; 6-3: 133-136]

Keywords: age, anxiety, education level, income, postmenopausal women, residence status
\end{abstract}

\begin{abstract}
Abstrak
Tujuan: Menganalisis faktor-faktor yang berhubungan dengan kecemasan pada perempuan pascamenopause.

Metode: Penelitian ini merupakan penelitian deskriptif analitik dengan pendekatan potong lintang yang dilakukan pada 228 perempuan pascamenopause yang berusia 50-64 tahun yang tinggal di daerah pesisir Kota Kendari. Pengambilan sampel dilakukan secara simpel random sampling. Teknik pengumpulan data menggunakan kuesioner dan mengacu pada Taylor Manifest Anxiety Scale (T-MAS). Analisis data menggunakan uji Chi-square dengan tingkat kemaknaan $p \leq 0,05$.

Hasil: Penelitian ini mendapatkan bahwa 188 responden (82,4\%) mengalami kecemasan. Kecemasan terbanyak dialami oleh mereka yang berusia 50-54 tahun (37,7\%), tingkat pendidikan rendah (96,0\%), sebagai ibu rumah tangga (62,7\%), berpenghasilan rendah (91,2\%) dan tinggal bersama pasangannya (54,4\%). Terdapat hubungan antara kecemasan dengan usia $(p=0,016)$, tingkat pendidikan $(p=0,009)$, pendapatan $(p=0,011)$, dan status tinggal $(p=0,029)$. Tidak terdapat hubungan antara kecemasan dengan pekerjaan $(p=0,351)$.

Kesimpulan: Terdapat hubungan antara kecemasan pada perempuan pascamenopause di daerah pesisir dengan usia, tingkat pendidikan, pendapatan, dan status tinggal.

[Maj Obstet Ginekol Indones 2018; 6-3: 133-136]
\end{abstract}

Kata kunci: kecemasan, pendapatan, perempuan pascamenopause, status tinggal, tingkat pendidikan, usia

\section{INTRODUCTION}

Menopause is a natural process experienced by every woman. A number of symptoms can be found due to hormonal changes that occur during menopause, including psychiatric, somatovegetative, and urogenital symptoms. ${ }^{1,2}$ Low steroid hormone concentrations during menopause are associated with memory impairment, lack of concentration, anxiety, depression, irritability, insomnia, and libido disorders. These symptoms can disrupt the quality of life of menopausal women.-5
Although menopause is a natural process, some women have a lot of worries when entering the menopause. Psychiatric problems often experienced is anxiety. Anxious because of the feelings of old age, unattractive, worrying about sexual desire decreases and feels useless and does not produce anything.6,7 Restlessness, irritability, depression, anxiety, and sleep disturbances are the most common complaints at the consultation to a doctor. ${ }^{3}$ 
Mild anxiety and stress vulnerability are common in the premenopausal period; while anxiety, depression, and irritability are more intense during perimenopause. Anxiety disorders tend to be more chronic compared to mood disorders (i.e., depression) in a woman suffering during the menopause. ${ }^{3}$ Previous study has shown that $75 \%$ of menopausal women feel menopause as a problem or disorder, while the other $25 \%$ do not question it. ${ }^{8}$ Anxiety in the face of menopause is associated with perceptions about menopause, that is positive perception hence lower level of mother's anxiety in the face of menopause. ${ }^{9}$ Anxiety in the face of menopause is associated with level of knowledge, the less knowledge means that the increasing anxiety in the face of menopause. ${ }^{10}$ The purpose of this study was to analyze the factors associated with anxiety in postmenopausal women in coastal areas.

\section{METHODS}

This study used cross-sectional approach on postmenopausal women in coastal area of Kendari City in December 2016. Samples were postmenopausal women aged 50-64 years old who meet inclusion and exclusion criteria.

Sampling was done by simple random sampling with a sample size of 228. Technique of collecting data used questionnaire and refer to Taylor Manifest Anxiety Scale (T-MAS), which contains physical, psychological, social and sexual aspects in marriage with ordinal measurement scales. Data were analyzed using Chi-square test with significance value $\mathrm{p} \leq 0.05$.

\section{RESULTS}

The study was conducted on 228 participants. Table 1 demonstrates the demographic characteristic of participants. Most participants were aged 50-54 years old, low education level, as housewife, low income and live with a partner.
Table 1. Demographic Characteristic of the Subjects

\begin{tabular}{lc}
\hline \hline \multicolumn{1}{c}{ Variables } & n (\%) \\
\hline Age & \\
$50-54$ & $86(37.7)$ \\
$55-59$ & $62(27.2)$ \\
$60-64$ & $80(35.1)$ \\
Level of education & $219(96.1)$ \\
Low & $9(3.9)$ \\
High & \\
Occupation & $85(37.3)$ \\
Employees & $143(62.7)$ \\
Housewife & \\
Income & $208(91.2)$ \\
Low & $20(8.8)$ \\
Sufficient & $124(54.4)$ \\
Residence status & $104(45.6)$ \\
With a partner & \\
With family &
\end{tabular}

Table 2 shows the distribution of anxiety in postmenopausal women in coastal areas. There were $82.5 \%$ postmenopausal women in coastal areas with anxiety.

Table 2. Distribution of Anxiety among the Subjects

\begin{tabular}{lc}
\hline \hline Variables & n (\%) \\
\hline Anxiety & $188(82.5)$ \\
Nonanxiety & $40(17.5)$ \\
\hline \hline
\end{tabular}

Table 3 shows correlation between some variable with anxiety in postmenopausal women in coastal areas. There was a significant correlation between anxiety with age $(\mathrm{p}=0.016)$, education level $(p=0.009)$, income $(p=0.011)$, and residence status $(p=0.029)$. There was no significant correlation between anxiety with occupation $(\mathrm{p}=0.351)$.

Table 3. Correlation between some Variable with Anxiety in Postmenopausal Women in Coastal Areas

\begin{tabular}{rccc}
\hline \hline \multicolumn{1}{l}{ Variables } & Anxiety n (\%) & Non Anxiety n (\%) & p-value \\
\hline \multicolumn{1}{l}{ Age } & & & \\
$50-54$ & $79(34.6)$ & $15(6.1)$ & 0.016 \\
$55-59$ & $47(20.6)$ & $18(7.9)$ &
\end{tabular}




\begin{tabular}{lccc}
\hline \hline Variables & Anxiety n (\%) & Non Anxiety n (\%) & p-value \\
\hline Education level & $184(80.7)$ & $35(15.3)$ & 0.009 \\
$\quad$ Low & $4(1.8)$ & $5(2.2)$ & \\
$\quad$ High & & & 0.351 \\
Occupation & $67(29.4)$ & $18(7.9)$ & \\
$\quad$ Employees & $121(53.1)$ & $22(9.6)$ & 0.011 \\
$\quad$ Housewife & $176(77.2)$ & $32(14.0)$ & \\
Income & $12(5.3)$ & $8(3.5)$ & \\
$\quad$ Low & $109(47.8)$ & $15(6.6)$ & 0.029 \\
$\quad$ Sufficient & $79(34.7)$ & $25(10.9)$ & \\
Residence status & & \\
$\quad$ With a partner & & & \\
With family & &
\end{tabular}

\section{DISCUSSION}

The largest group of postmenopausal women in coastal areas who experienced anxiety were those who aged 50-54 years old. The World Health Organization (WHO) indicates that menopause occurs at an average age of 45-55 years old around the world. Previous research has found that between the ages of 42 to 52 years, women with high levels of anxiety during premenopause continue to experience this during menopause. ${ }^{3}$ Premenopausal woman with low anxiety levels can be more susceptible to increased levels of anxiety during and after menopause transition. ${ }^{11}$ While other studies have found that postmenopausal women, aged between 45 and 55, have high levels of anxiety compared to premenopausal women between 35 and 45.12

This study found that there was correlation between anxiety in postmenopausal women with age. This is in contrast with previous study that found there was no correlation between age with anxiety in premenopausal and perimenopausal women. 8,13

This study found that most of the anxiety occurred in the low education respondents. Previous study has found that there is a significant correlation between education levels with anxiety in premenopausal women. The higher education, the acceptance of information will be easier, able to think rationally and openly with new ideas. Acceptance of information and knowledge about menopause will support the readiness of facing menopause. ${ }^{13}$ Anxiety in the face of menopause is not associated with education level. There is significant influence on knowledge and anxiety of perimenopausal women. . $^{8,10}$

The group with the most anxiety is housewives. Previous study found that there was a significant correlation between occupation and anxiety in premenopausal women. ${ }^{13}$ There was no significant influence between occupation and anxiety in perimenopausal women. ${ }^{8}$ The activities of women can affect the quality of life. Work is something done to earn a living or livelihood. There is an element of need in work. Anxiety in postmenopausal women may come from both of the work itself and the process leading to menopause. $^{8,13}$

The study found that there was relationship between income with anxiety in postmenopausal women. The anxiety in postmenopausal woman will decrease if she has enough income. The ability to daily meet needs can affect quality of life. The ability to daily meet needs will reduce the complaints of menopausal women, who feel old and cannot do anything. This was not agreed with the previous study that there was no significant influence between economic conditions and anxiety in perimenopausal women. ${ }^{8}$ Depression in postmenopausal women can be associated with socioeconomic statuses such as education and income. ${ }^{6}$

The study found that there was correlation between the residence status with anxiety in 
postmenopausal women. There was a significant correlation between family social support with anxiety in the face of menopause. ${ }^{13}$ Family support, both material and non-material assistance, causes the individual to feel cared for, valued, loved and accepted in the family. The older, the more changes that can make a woman feel anxious. Anxious because of the feelings of old age, unattractive, worrying about sexual desire decreases and feels useless and does not produce anything. 6,7 These conditions need a separate concern so that required understanding of the husband and children as members of the immediate family. ${ }^{8}$

Husband's support greatly affects women in the face of menopause. In this study, it was found that participants with the most anxiety were those living with a partner. Women will feel depressed because they lose her role as a woman in her old age. At that time a woman needs positive support such as helping with household chores. Good communication must be maintained in order to understand each other and find the best solution if it becomes a problem.

\section{CONCLUSION}

There is correlation between anxiety in postmenopausal women in coastal areas with age, education level, income and residence status. There is no correlation between anxiety in postmenopausal women in coastal areas with occupation.

\section{REFERENCES}

1. Baziad, A. Gambaran Klinis, Terapi dan Pencegahan Menopause. Menopause dan Andropause. Jakarta: Yayasan Bina Pustaka Sarwono Prawirohardjo; 2003: 1-18.
2. Heinemann, L. International versions of the Menopause Rating Scale (MRS). Bio Med Central, 2003: 1-4.

3. Rodríguez-Landa JF, Puga-Olguín A, Germán-Ponciano LJ, García-Ríos RI, Soria-Fregozo C. Anxiety in Natural and Surgical Menopause-Physiologic and Therapeutic Bases. In : A Fresh look at anxiety disorders; 2015; 173-98 Acces from: http://www.intechopen.com/books/a-fresh-look-at-anxie tydisorders

4. Yang SG, Mlcek M, Kittnar O. Estrogen can modulate menopausal women's heart rate variability. Physiol Research. 2013; 62: 165-71.

5. Erekson EA, Martin DK, Ratner ES. Oophorectomy: the debate between ovarian conservation and elective oophorectomy. Menopause 2013; 20(1): 110-4.

6. Afshari P, Manochehri S, Tadayon M, Kianfar M, Haghighizade M. Prevalence of Depression in Postmenopausal Women. Jundishapur J Chronic Dis Care. 2015; 4(3): e27521.

7. Parmitasari DLN, Prawitasari JE, Indati A. Kecemasan pada Perempuan Menopause ditinjau dari Status Perkawinan. Psikodimensia. Kajian Ilmiah Psikologi. 2002; 3(1): 9-14.

8. Aprilia NI, Puspitasari N. Faktor yang Mempengaruhi Tingkat Kecemasan Perempuan Perimenopause, Surabaya. Indones J Public Health. 2007; 4: 35-42.

9. Christiani, Retnowati S, Purnamaningsih EH. Hubungan persepsi tentang menopause dengan tingkat kecemasan pada perempuan yang menghadapi menopause. J Psikol. 2000; 2: 96-100.

10 Damayanti F. Hubungan tingkat pengetahuan dan upaya penanganan ibu dengan kecemasan dalam menghadapi menopause di Kelurahan Genuksari Kecamatan Genuk Kota Semarang. J Dinamika Keb. 2012; 2(1): 1-14.

11. Bromberger JT, Kravitz HM, Chang Y, Randolph JF Jr, Avis NE, Gold EB, Matthews KA. Does risk for anxiety increase during the menopausal transition? Study of women's health across the nation. Menopause. 2013; 20(5): 488-95.

12. Jafari F, Hadizadeh MH, Zabihi R, Ganji K. Comparison of depression, anxiety, quality of life, vitality and mental health between premenopausal and postmenopausal women. Climacteric 2014; 17(6): 660-5.

13. Saimin J, Hudfaizah C, Hafizah I. Kecemasan perempuan premenopause dalam menghadapi masa menopause, Sebuah studi cross sectional. JK Unila. 2016; 1(2): 226-30. 